\title{
Galactokinase deficiency
}

INSERM

\section{Source}

INSERM. (1999). Orphanet: an online rare disease and orphan drug data base.

Galactokinase deficiency. ORPHA:79237

Galactokinase deficiency is a rare mild form of galactosemia (see this term)

characterized by early onset of cataract and an absence of the usual signs of classic

galactosemia, i.e. feeding difficulties, poor weight gain and growth, lethargy, and jaundice. 